\title{
Effects of cadmium on acetylcholinesterase activities and histopathology of African catfish (Clarias gariepinus) from contaminated fish farm in Mae Sot District, Tak Province, Thailand
}

\author{
Supisara Suwanprasert ${ }^{\mathrm{a}}$, Supap Saenphet ${ }^{\mathrm{b}}$, Wararut Buncharoen ${ }^{\mathrm{b}}$, Songyot Kullasoot ${ }^{\mathrm{c}}$, \\ Nattawut Sareein ${ }^{\mathrm{c}}$, Chitchol Phalaraksh ${ }^{\mathrm{b}, \mathrm{c}, *}$ \\ a $\mathrm{PhD}$ Degree Program in Environmental Science, Environmental Science Research Center, Faculty of \\ Science, Chiang Mai University, Chiang Mai 50200 Thailand \\ b Department of Biology, Faculty of Science, Chiang Mai University, Chiang Mai 50200 Thailand \\ c Environmental Science Research Center, Faculty of Science, Chiang Mai University, Chiang Mai 50200 \\ Thailand
}

*Corresponding author, e-mail: chitchol.p@cmu.ac.th

\begin{abstract}
This study was aimed at evaluating the effects of cadmium (Cd) on bioaccumulation, acetylcholinesterase (AChE) activities and histopathological alteration in African catfish (Clarias gariepinus) from a contaminated fish farm in Mae Sot District, Tak Province, western Thailand. Along with water and sediment samplings, fish samples were collected from the contaminated fish farm after two, four and six months of cultivation. The Cd accumulation in liver and muscle of $C$. gariepinus were measured. Moreover, the effects of Cd on AChE activities in brain, kidney, liver, and muscle were studied. The results showed that Cd concentrations in water of Mae Tao Stream and fish pond ranged $0.001-0.038 \mathrm{mg} / \mathrm{l}$, while in the sediments ranged $0.367-21.250 \mathrm{mg} / \mathrm{kg}$. Cadmium concentration in the liver of C. gariepinus was higher than in the muscle, i.e., $0.190 \mathrm{mg} / \mathrm{kg}$ (range $0.150-0.270 \mathrm{mg} / \mathrm{kg}$ ) and $0.030 \mathrm{mg} / \mathrm{kg}$ (range $0.020-0.040 \mathrm{mg} / \mathrm{kg}$ ), respectively. AChE activities showed significant increase in the brain and the muscle and decrease in the kidney and the liver. In addition, after six months of fish cultivation, AChE activities were found significantly decreased in the liver. Furthermore, histopathological alterations were observed in the gills, the kidney and the liver after exposure, i.e., loss of all mucus membranes of the gills, distortion of capillaries of glomerulus in kidneys and large vacuoles in liver tissues. These results are useful for biomarker of Cd contamination in the aquatic environment.
\end{abstract}

KEYWORDS: cadmium, acetylcholinesterase, African catfish, histopathology, aquatic toxicology

\section{INTRODUCTION}

Cadmium (Cd) is a ubiquitous trace metal, biochemically classified as a nonessential element [1]. It occurs naturally in aquatic environments and is released as a result of anthropogenic activities such as mining [2]. Cd is a highly toxic metal to human and environment which can be contaminated in sediments and aquatic organisms [3]. The Cd contamination has been found in natural soils concomitantly with zinc (Zn) mining activities [4]. It can be exposed to human body through respiratory system and digestive tract by consumption of contaminated food and water [5], and eventually causing severe diseases (e.g. Itai-itai), renal destruction and death [6]. Moreover, Cd can be accumulated in human body through the food chain, and inflows into aquatic ecosystems [4].

In Thailand, the highest $\mathrm{Zn}$ and $\mathrm{Cd}$ deposits were reported in Mae Sot District, Tak Province, a result of $\mathrm{Zn}$ mining activities that have been actively operating for more than 30 years [7]. Several researchers revealed that the concentrations of $\mathrm{Cd}$ in soil and sediment around Mae Tao Stream, Mae Sot District, Tak Province ranged from 0.847.86 and $3.40-284.00 \mathrm{mg} / \mathrm{kg}$, respectively. The maximum Cd concentrations in those studies were about 100 times higher than the European Economic Community (EEC) Maximum Permissible (MP), and about 1800 times higher than the standard of Thailand $[7,8]$. Moreover, Cd does not degrade easily into the environment, and can be bioaccumulated 
in organism for several years after exposure to low levels [9].

Mae Tao Stream is the main water resource for agricultural crops of rice, soybean, corn, sugarcane and garlic cultivations in Mae Sot District, Tak Province, Thailand [10]. Moreover, the water resource is also used for domestic and aquaculture activities, especially fish farming. The heavy metals can be accumulated in fish tissues by the absorption along their gill surface and gastrointestinal tract wall, which can cause higher levels of toxic concentration in the body than their environment [11]. Cadmium usually accumulated less in gills since they are a temporary target organ of accumulation, unlike the digestive and reproductive organs [12]. Previous studies showed the alterations of AChE activities and histopathology in fish (e.g., Silver catfish [13] and White seabass [14]) depending on $\mathrm{Cd}$ concentration level. However, there are only few studies on the effects of $\mathrm{Cd}$ contamination in aquatic organism [7], especially, the effects of Cd on AChE activity and histopathological alteration in aquatic organisms due to Cd accumulation.

African catfish (Clarias gariepinus) was chosen for this study because of its importance in the aquaculture industry of Thailand. In 2016, production of Thailand was around $122418 \mathrm{mt}$ which ranked second after Nigeria when the global production was $231094 \mathrm{mt}$ [15]. The fish was also reported to have the genetically distinct stocks that are useful for selective breeding program [16]. Since the local farmers use water from Mae Tao Stream to supply their fish ponds in dry season, therefore, the investigation of $\mathrm{Cd}$ concentration in water, sediment and tissue samples of African catfish C. gariepinus, as well as, their AChE activities and histopathological alteration, are highly required.

\section{MATERIALS AND METHODS}

\section{Study sites}

The two sampling sites on Mae Tao Streams (MT1 and MT2) and the selected fish farms were located in Phra That Padaeng Sub-district, Mae Sot District, Tak Province, Western Thailand (Fig. 1). Site MT1 is located at the upstream of Padaeng Zinc Mining $\left(16^{\circ} 40^{\prime} 4.57^{\prime \prime} \mathrm{N}, 98^{\circ} 42^{\prime} 4.89^{\prime \prime} \mathrm{E}\right)$ and was defined as reference site. Site MT2 is located in the Mae Tao Stream $\left(16^{\circ} 40^{\prime} 18^{\prime \prime} \mathrm{N}, 98^{\circ} 37^{\prime} 10^{\prime \prime} \mathrm{E}\right)$ which passes through Cd contaminated area from the $\mathrm{Zn}$ mining. The selected fish farm is operated near MT2 and uses water from the stream as its water resource.

\section{Water, sediment and African catfish sampling}

Two week old juvenile African catfish, with unknown whole body Cd concentration (detection was not performed), were released into the pond in June 2015. Three replicates of water and sediment samples were collected from the fish farm bimonthly between August and December 2015. Those water and sediment samples were preserved in polyethylene bottles at $4^{\circ} \mathrm{C}$ until laboratory analysis of $\mathrm{Cd}$ concentration was performed [17]. Twenty fish samples were collected bimonthly between August and December 2015. Fish samples were kept in a cool box for determination of AChE activities and histopathological alteration in their tissues and compared with fish samples with no Cd contamination.

\section{Analysis of cadmium in water and sediment samples}

Water samples were digested in nitric acid and filtered. The filtrate was diluted to $100 \mathrm{ml}$ with deionized water [18]. Sediment samples were dried at $140^{\circ} \mathrm{C}$ in a hot air oven for four hours, and then $500 \mathrm{mg}$ of the sample was digested in a $2: 1$ $\mathrm{HClO}_{4}: \mathrm{NHO}_{3}$ using an open tube digestion method and block digester [19]. The digested samples were diluted to $25 \mathrm{ml}$ with deionized water. $\mathrm{Cd}$ concentrations were determined by using an atomic absorption spectrophotometer at $228.8 \mathrm{~nm}$ (AAS with LOD $0.003 \mathrm{mg} / \mathrm{kg}$ ) [17].

\section{Analysis of cadmium in African catfish samples}

Fish samples were dissected to separate liver and muscles. The liver and muscles were dried at $80^{\circ} \mathrm{C}$ for two days to constant weight and then digested in concentrated nitric acid at $110^{\circ} \mathrm{C}$ for three days. All digested samples were diluted to appropriate concentrations for analysis using inductively coupled plasma optical emission spectroscopy (ICP-OES) [20].

\section{Analysis of AChE activities in African catfish samples}

Acetylcholinesterase activity was measured following Ellman et al [21]. Individually, $20 \mathrm{mg}$ of brain, kidney, liver and muscle tissues were weighed and placed in separate homogenizing tubes in ice during homogenization. The samples were homogenized with 0.1 M Phosphate buffer saline (PBS, $\mathrm{pH}$ 8.0) $1 \mathrm{ml}$ and centrifuged at $3500 \mathrm{rpm}$ for $10 \mathrm{~min}$. Next, $20 \mu \mathrm{l}$ of the supernatant was mixed with $1.3 \mathrm{ml}$

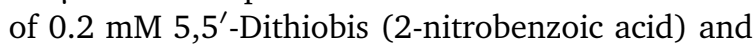
$63 \mu \mathrm{l}$ of $0.75 \mathrm{mMATChI}$. The solution was removed 


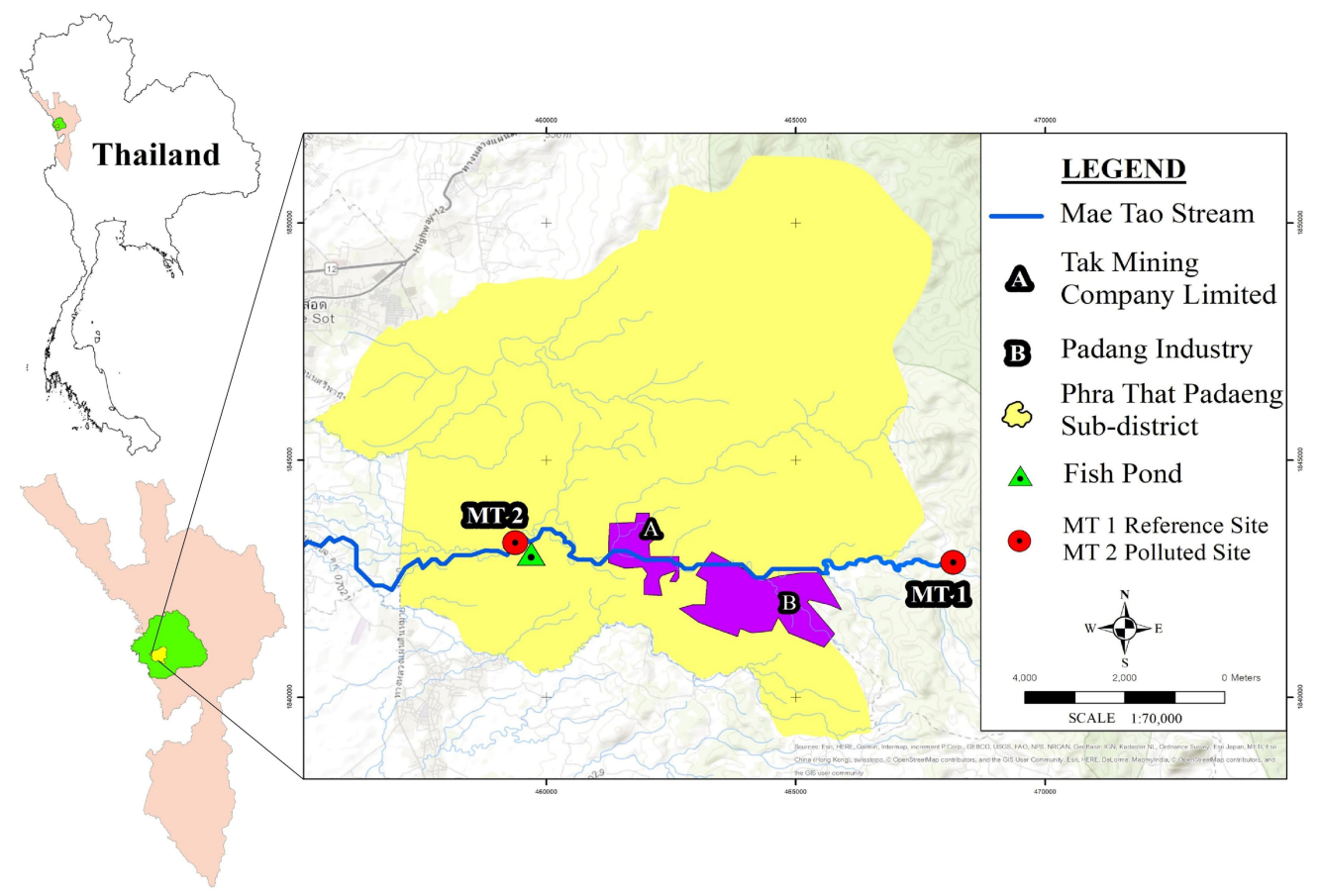

Fig. 1 Sampling sites on Mae Tao Stream and fish farm in Mae Sot District, Tak Province, Western Thailand.

to microplate $250 \mu \mathrm{l}$ and analyzed at $405 \mathrm{~nm}$ every 2 min for 10 min using Elisa reader. All statistical analyses were accomplished by mean \pm SD and oneway ANOVA using SPSS statistics version 17.0 (SPSS Inc., Chicago, IL, USA), with a significant threshold of $p<0.05$.

\section{Analysis of histopathological alteration in African catfish samples}

Samples of gills, liver and kidney were dissected, separated and fixed in Bouin's fluid for $24 \mathrm{~h}$. All tissues were washed several times in $70 \%$ ethanol, dehydrated in a graded series of ethanol, embedded in paraffin, and sectioned at 6-8 $\mu \mathrm{m}$ thickness. The sections were stained with hematoxylin and eosin staining, and then examined under light microscope [22].

\section{RESULTS AND DISCUSSION}

\section{Cd concentrations in water, sediment and African catfish samples}

Cd concentrations in water and sediment samples are shown in Table 1 . The Cd concentrations in water ranged from 0.001 to $0.038 \mathrm{mg} / 1$. The highest $\mathrm{Cd}$ concentration was found in fish farm. However, these concentrations did not exceed the values of the Surface Water Quality Standard of Thailand
(0.05 mg/l). The Cd concentration in sediments ranged from 0.367 to $21.250 \mathrm{mg} / \mathrm{kg}$ and the highest concentration was found in MT2 which was similar to other studies that Mae Tao Stream received contaminated sediment loading from Zn mining at the upstream into the downstream [7]. In addition, most of the sediments from Mae Tao Stream and fish farm were contaminated by Cd that clearly exceeded the European Maximum Permissible Levels (>3.0 $\mathrm{mg} / \mathrm{kg}$ ).

According to Cd concentrations in African catfish tissues, the $\mathrm{Cd}$ concentrations in muscle and liver of $C$. gariepinus were not exceeded the suggestion value $(<0.5 \mathrm{mg} / \mathrm{kg})$ from FAO [23]. However, these results indicated that $\mathrm{Cd}$ can be accumulated more in liver than muscle (Table 1). This agreed with several previous studies in C. gariepinus, Rhamdia quelen, and in Tilapia nilotica $[1,13,24]$. In this study, the highest Cd concentration was found in liver of C. gariepinus after rearing in the contaminated fish farm for two months and gradually decreased at four and six months of exposure. The increase of Cd level in liver was due to Cd detoxification by metallothioneins (MT) binding activity in the liver $[1,25]$. Moreover, several studies have shown that the liver is the most important organ for Cd detoxification in fish $[3,12]$. In the liver, $\mathrm{Cd}$ concentration increases rapidly until its capacity 
Table 1 Cadmium concentration in water, sediment and fish organs collected from Mae Tao Stream and the fish farm.

\begin{tabular}{|c|c|c|c|}
\hline \multirow{2}{*}{ Sampling site } & \multicolumn{3}{|c|}{ Duration time of exposure } \\
\hline & Aug (2 months) & Oct (4 months) & Dec (6 months) \\
\hline \multicolumn{4}{|l|}{ MT1 } \\
\hline water $(\mathrm{mg} / \mathrm{l})$ & $0.001 \pm 0.001$ & $0.007 \pm 0.003$ & $0.004 \pm 0.001$ \\
\hline sediment $(\mathrm{mg} / \mathrm{kg})$ & $1.117 \pm 0.321$ & $1.333 \pm 0.161$ & $0.367 \pm 0.104$ \\
\hline \multicolumn{4}{|l|}{ MT2 } \\
\hline water $(\mathrm{mg} / \mathrm{l})$ & $0.008 \pm 0.004$ & $0.002 \pm 0.001$ & $0.006 \pm 0.001$ \\
\hline sediment $(\mathrm{mg} / \mathrm{kg})$ & $18.900 \pm 8.835$ & $13.183 \pm 1.249$ & $21.250 \pm 9.916$ \\
\hline \multicolumn{4}{|l|}{ Fish farm } \\
\hline water $(\mathrm{mg} / \mathrm{l})$ & $0.038 \pm 0.040$ & $0.005 \pm 0.004$ & $0.004 \pm 0.002$ \\
\hline sediment $(\mathrm{mg} / \mathrm{kg})$ & $6.833 \pm 1.540$ & $7.844 \pm 0.920$ & $3.611 \pm 1.940$ \\
\hline muscle $(\mathrm{mg} / \mathrm{kg})$ & $0.037 \pm 0.009$ & $0.022 \pm 0.002$ & $0.028 \pm 0.010$ \\
\hline liver $(\mathrm{mg} / \mathrm{kg})$ & $0.274 \pm 0.150$ & $0.146 \pm 0.090$ & $0.164 \pm 0.080$ \\
\hline
\end{tabular}

Values are represented as mean \pm standard deviation from three independent experiments.

limitation, then Cd could reach and accumulate in other organs such as muscle $[3,12,26]$. The high accumulation of $\mathrm{Cd}$ in liver was related to the fact that the liver plays a role in accumulation and detoxification [27]. However, after six months of exposure in contaminated fish farm, the Cd level in the liver of $C$. gariepinus slightly increased, and the reason is perhaps the ability of detoxification organs was decreased or became dysfunctional [28].

\section{AChE activities in African catfish}

Heavy metals cause different responses of AChE activities, such as inhibition [13] and increase [29]. In this study, AChE activities of African catfish after two months of exposure were significantly increased in brain and muscle, and significantly decreased in kidney and liver. As shown in Fig. 2a, AChE activities in brain and muscle were higher than kidney and liver, these results were similar to those suggested by Ventura et al [30]. AChE plays an important role in removing the neurotransmitter acetylcholine within the synapse through hydrolysis [31]. These results may affect fish behavior, i.e., motion balance, swimming or feeding, because it is related to AChE activity in brain and muscle [32,33]. These results also showed biological responses toward Cd contaminant for survival in environmental stress.

AChE activities of African catfish after four months of exposure were not significantly decreased in any organs (Fig. 2b). The results were similar to a previous study in Cyprinus carpio [34]. However, AChE activities showed a decreasing tendency when compared with control group. The same results were reported in Ramdia quelen [13]. On the other hand, when fish are exposed to $\mathrm{Cd}$, they synthesize the detoxifying protein such as metallothionein (MT), in kidney and liver [35]. Moreover, Dang and Wang [36] reported that Cd exposure to Terapon jarbua was correlated to the increase of MT concentration in its liver, suggesting the role of MT on metal detoxification. Thus, it could be expected that MT induction occurred and acted against the effect of Cd on AChE activity. Therefore, in four months, AChE activities were not significantly decreased in any organs.

AChE activities of African catfish after six months of exposure were not significantly decreased in kidney and muscle, whereas in the brain it was significantly increased and found to be significantly decreased in liver (Fig. 2c). Long term exposure to $\mathrm{Cd}$ resulted in neurotoxicity in brain and liver. AChE activities were interfered by high dose of $\mathrm{Cd}$ and time response, resulting in the accumulation of $\mathrm{Cd}$ in liver which caused liver dysfunction, and followed by $\mathrm{Cd}$ accumulation in other organs. Whereas AChE in brain was higher than the control, the same as a previous study [34]. The alteration of AChE activities may affect fish behavior such as swimming or feeding [13], and reduce survival leading to population-level effects as well [37].

\section{Histopathological alteration in African catfish}

The histopathological alterations were observed in gills, kidney and liver of $C$. gariepinus from the contaminated fish farm when compared to the control from non-contaminated fish farm. The normal gill tissues included secondary lamellae lined up along both sides of the primary lamellae. The primary 


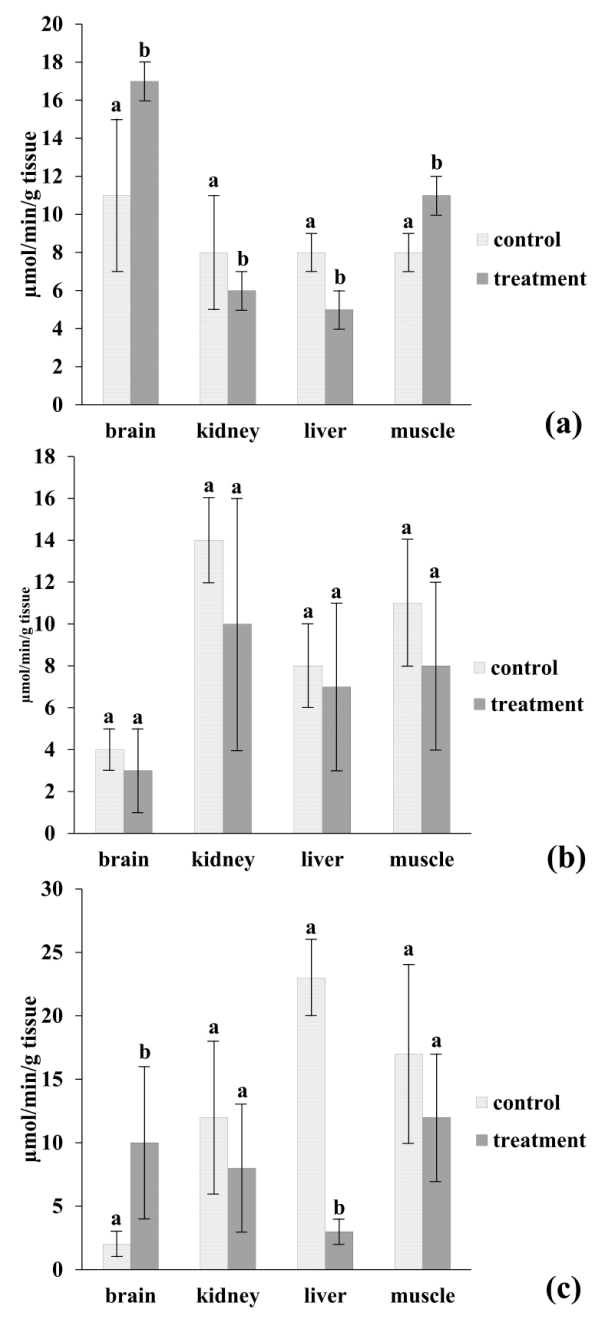

Fig. 2 Acetylcholinesterase activities in African catfish after (a) 2 months of exposure, (b) 4 months of exposure, and (c) 6 months of exposure in brain, kidney, liver and muscle.

lamellar were covered with epitheliual tissue and mucus membrane with epithelial cells inside and not separated from chondrocyte. Higher magnification (Fig. 3a) showed epithelial cells and large number of mucus cells. Whereas, gills of $C$. gariepinus exposed in contaminated fish farm for two and four months showed histopathological alterations i.e. losses of epithelial tissue in secondary lamellae and less mucus cells. Moreover, secondary lamellae showed hyperplasia of epithelial cell (yellow arrow). The secondary lamellae also showed destruction of either epithelial cells or a few lamellae were curled, leading to congestion and hemorrhage of gills (Fig. 3b). Whilst, the secondary lamellae

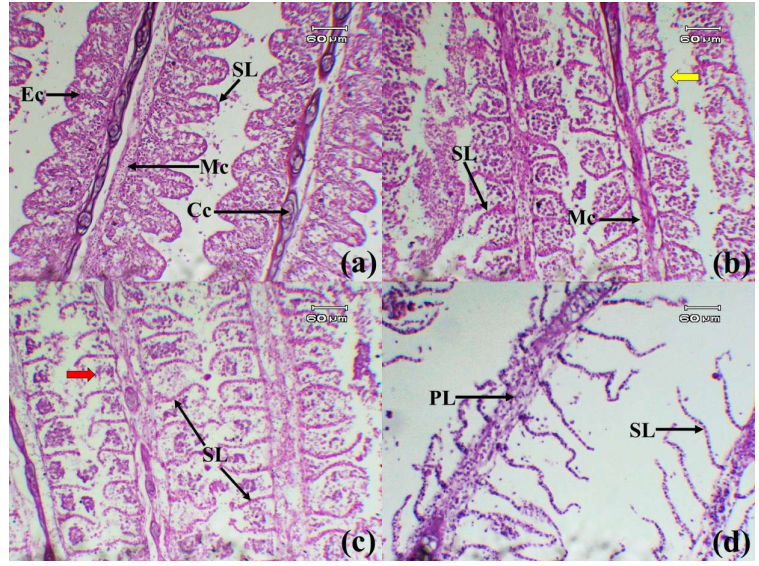

Fig. 3 Transverse section of African catfish's primary lamellae gill: (a) control, (b) 2 months of exposure, (c) 4 months of exposure, and (d) 6 months of exposure. Cc, chondrocyte; PL, primary lamellae; SL, secondary lamellae; Mc, mucus cells; Ec, epithelial cells; yellow arrow, hyperplasia of epithelial cell; and red arrows, loss of epithelial cells.

at four months of exposure (Fig. 3c) showed the curled and loss of epithelium cells (red arrow). These results agreed with previous studies that reporting that the gills of fish exposed to $\mathrm{Cd}$ showed thickening of the primary lamellar epithelium and clubbing of secondary lamellae [14, 22]. Moreover, serious symptoms were observed in gills after six months of exposure i.e. loss of all mucus membrane and epithelial cells (Fig. 3d). These alterations may negatively affect gill function causing decrease efficiency of osmotic regulation, ion regulation and respiration [14].

With regard to kidney and liver tissues, the histopathological alterations were observed after four months of exposure. The alteration of kidney tissues (Fig. 4c-d) was represented by wider lumen of proximal and distal tubules (PT and DT), distortion and broadening of Bowman's capsule (BC), distortion of glomerulus (G) capillaries. Whereas those alterations were not observed in both the control and the two months of exposure (Fig. 4a-b). Kidney tissues such as renal tubular epithelium is particularly sensitive to poisons. The highly metabolic proximal tubules are most seriously affected by toxin. In Tilapia mossambica, after it was exposed to $\mathrm{Cd}$, the cell size of kidney was reduced, and the glomerular tissues remained more or less intact. Also damage of interstitial edema and renal tubes in several areas were observed. In addition, the hydrophobic degeneration of renal tubes in the 


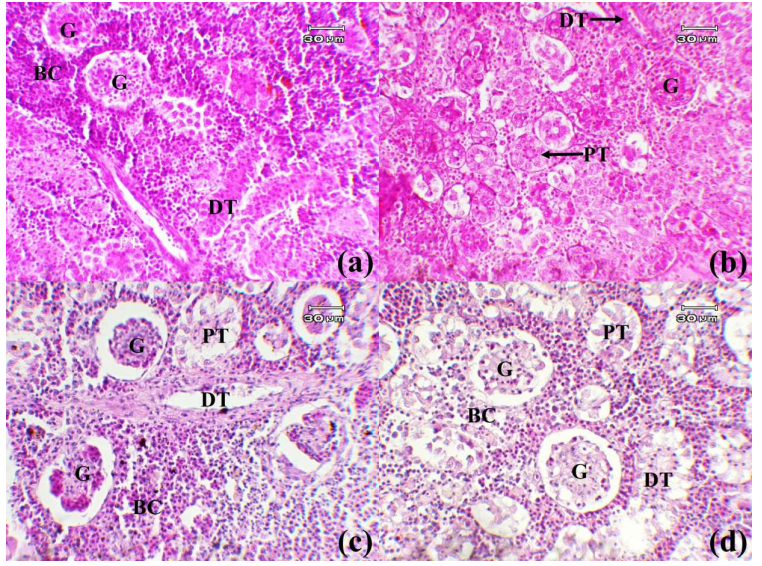

Fig. 4 Transverse sections of African catfish's kidney: (a) control, (b) 2 months of exposure, (c) 4 months of exposure, and (d) 6 months of exposure. G, glomerulus; PT, proximal tubules; DT, distal tubules; and BC, Bowman's capsule.

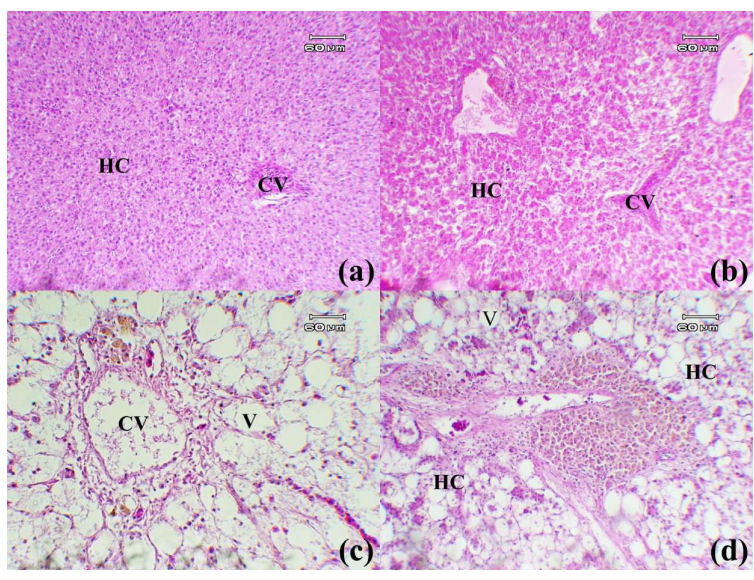

Fig. 5 Transverse sections of African catfish's liver: (a) control, showing normal exo-structure of hepatic cells (HC); (b) 2 months of exposure, showing hemorrhagic tissues and central vein (CV); (c) 4 months of exposure, showing sponge condition and large vacuole (V); and (d) 6 months of exposure, showing large number of vacuoles.

glomerular tissues has been observed [38].

Histopathological effects of Cd on liver tissue, such as hemorrhage, were observed in two months of exposure (Fig. 5b), and severe damages in four and six months of exposure (Fig. 5c-d), i.e., losing of hepatic cells (HC), tissue converted into sponge and large vacuoles (V), and central vein (CV) exhibiting wider, when compared to the control (Fig. 5a). These results were similar to those previously re- ported in Mosquito fish (Gambusia affinis) that Cd caused liver tissue alterations [39]. These alterations cause serious modification of detoxification pathways in liver and kidney of fish [22]. All of the histopathological observations indicated that $\mathrm{Cd}$ contaminated farm can cause destructive effect in gill, kidney and liver tissues of $C$. gariepinus.

\section{CONCLUSION}

In this study, only Cd concentrations in sediment samples were higher than fish and water samples, which exceeded the standard of Thailand. In fish samples, Cd concentration in liver was higher than muscle. The inducing of AChE activities in brain and muscle of juvenile $C$. gariepinus could be used as biomarker for $\mathrm{Cd}$ pollution. Whereas, the decreasing of AChE activities in liver of $C$. gariepinus indicated long term exposure of Cd causing accumulation of Cd in the liver and organ's dysfunction. Moreover, histopathological alterations could be used as biomarkers of $\mathrm{Cd}$ contamination in the aquatic environment.

Acknowledgements: Our sincere acknowledgement and thanks go to the members of Freshwater Biomonitoring Research Laboratory and Medicinal Plants and Reproductive Research Laboratory, Department of Biology, Faculty of Science, Chiang Mai University for their assistance in sampling and the analyses of samples. Environmental Science Research Center, Faculty of Science, and Graduate School of Chiang Mai University are gratefully acknowledged. This research work was partially supported by Chiang Mai University.

\section{REFERENCES}

1. Rose S, Vincen S, Meena TB, Suresh A, Mani R (2014) Metallothionein induction in freshwater catfish Clarias gariepinus on exposure to cadmium. Int J Pharm Pharm Sci 6, 975-1091.

2. Alloway BJ (1990) Cadmium. In: Alloway BJ (ed) Heavy Metals in Soils, Blackie and Son Ltd., Glasgow, pp 100-124.

3. Cinier CC, Petit RM, Faure R, Garin D, Bouvet $Y$ (1999) Kinetics of cadmium accumulation and elimination in carp Cyprinus carpio tissues. Comp Biochem Physiol 122, 345-352.

4. Satarug S, Baker JR, Urbenjapol S, Haswell EM, Reilly PEB, Williams DJ, Moore MR (2003) A global perspective on cadmium pollution and toxicity in non-occupationally exposed population. Toxicol Lett 137, 65-83.

5. Kobayashi E, Suwazono Y (2006) Tolerable level of lifetime cadmium intake estimated as a benchmark dose low, based on excretion of $\beta_{2}$-microglobulin in 
the cadmium-polluted regions of the Kakehashi River Basin, Japan. Bull Environ Contam Toxicol 76, 8-15.

6. Ezaki T, Tsukhara T (2003) No clear-cut evidence for cadmium-induced renal tubular dysfunction among over 10,000 women in the Japanese general population: a nationwide large-scale survey. Int Arch Occup Environ Health 76, 186-196.

7. Weeraprapan P, Chantara S, Kawashima M, Roongruangwong W, Tagun R, Phalaraksh C (2018) Mouthpart deformities in non-biting midge larvae from a cadmium contaminated stream in Northern Thailand. ScienceAsia 44, 67-73.

8. Simmons RW, Pongsakul P, Saiyasitpanich D, Klinphoklap S (2005) Elevated levels of cadmium and zinc in paddy soils and elevated levels of cadmium in rice grain downstream of a zinc mineralized area in Thailand: implications for public health. Environ Geochem Health 27, 501-511.

9. Tchounwou PB, Yedjou CG, Patlolla AK, Sutton DJ (2012) Heavy metals toxicity and the environment. In: Luch A (ed) Molecular, Clinical and Environmental Toxicology, Springer, Berlin, Germany, pp 133-164.

10. Thanee I, Phalaraksh C (2012) Diversity of aquatic insects and their functional feeding group from anthropogenically disturbed streams in Mae Sot District, Tak Province, Thailand. Chiang Mai J SCI 39, 399-409.

11. Chevreuil M, Carru AM, Chesterikoff A, Boët P, Tales E, Allardi J (1995) Contamination of fish from different areas of the river Seine (France) by organic (PCB and pesticides) and metallic (Cd, $\mathrm{Cr}, \mathrm{Cu}, \mathrm{Fe}$, $\mathrm{Mn}, \mathrm{Pb}$ and $\mathrm{Zn}$ ) micropollutants. Sci Total Environ $162,31-42$.

12. Wu SM, Shin M, Ho Y (2007) Toxicological stress response and cadmium distribution in hybrid tilapia (Oreochromis sp.) upon cadmium exposure. Comp Biochem Physiol 145, 218-226.

13. Pretto A, Vania LL, Vera MM, Bibiana SM, Charlene M, Bárbara C, Lucélia H, Valderi D (2010) Acetylcholinesterase activity, lipid peroxidation, and bioaccumulation in silver catfish (Rhamdia quelen) exposed to cadmium. Arch Environ Contam Toxicol 58, 1008-1014.

14. Thophon S, Kruatrachuea M, Upathama ES, Pokethitiyooka P, Sahaphongb S, Jaritkhuanc S (2003) Histopathological alterations of white seabass, Lates calcarifer, in acute and subchronic cadmium exposure. Environ Pollut 121, 307-320.

15. FAO (2018) Fishery and Aquaculture Statistics. Global Aquaculture Production 1950-2016 (FishstatJ). FAO Fisheries and Aquaculture Department, Rome. [Available at: http://www.fao.org/fishery/ statistics/software/fishstatj/en.]

16. Wachirachaikarn A, Na-Nakorn U (2019) Genetic diversity of the North African catfish, Clarias gariepinus (Burchell, 1822) hatchery stocks in Thailand. ScienceAsia 45, 301-308.
17. Wencuan Q, Dickman M, Sumin W (2001) Multivariate analysis of heavy metal and nutrient concentrations in sediments of Taihu Lake, China. Hydrobiologia 450, 83-89.

18. American Public Health Association (2012) Standard Methods for the Examination of Water and Waste Water, 22nd edn, APHA, AWWA, WEF, Washington, DC, USA.

19. Zarcinas BA, Cartwright B, Spouncer LR (1987) Nitric digestion and multi-element analysis of plant material by inductive coupled plasma spectrometry. Commun Soil Sci plan 18, 131-146.

20. Merian E (1991) Metal and their Compounds in the Environment: Occurrence, Analysis and Biological Relevance, VCH, Weinheim, Germany.

21. Ellman GL, Courtney KD, Andres VJ, Feather SRM (1961) A new and rapid colorimetric determination of acetylcholinesterase activity. Biochem Pharmacol 7, 88-95.

22. Wangsongsak A, Utarnpongsa S, Kruatrachue M, Ponglikitmongkol M, Pokethitiyook P, Sumranwanich $\mathrm{T}$ (2007) Alterations of organ histopathology and metallothionein mRNA expression in silver barb, Puntius gonionotus during subchronic cadmium exposure. J Environ Sci 19, 1341-1348.

23. Food and Agriculture Organization of the United Nation (2011) Joint FAO/WHO food standards programme codex committee on contaminations in foods (fifth session). [Available at: https://www.fao.org/tempref/codex/Meetings/ CCCF/CCCF5/cf05_INF.pdf.]

24. Kargin F, Çoğun HY (1999) Metal interaction during accumulation and elimination of zinc and cadmium in tissue of the freshwater fish Tilapia nilotica. Bull Environ Contam Toxicol 63, 511-519.

25. Wimmer U, Wang Y, Georgiev O, Schaffner W (2005) Two major branches of anti-cadmium defense in the mouse: MTF-1 metallothionein and glutathione. Nucleic Acids Res 33, 5715-5727.

26. Cinier CC, Petit RM, Faure R, Garin D (1997) Cadmium bioaccumulation in carp (Cyprinus carpio) tissues during long term high exposure: analysis by inductively coupled plasma mass spectrometry. Ecotoxicol Environ Safety 38, 137-143.

27. Gbem TT, Balogun J, Lawal FA, Annune PA (2001) Trace metal accumulation in Clarias gariepinus (Teugels) exposed to sublethal levels of tannery effluent. Sci Total Environ 271, 1-9.

28. Asagba SO, Eriyamremu GE, Igberaese ME (2008) Bioaccumulation of cadmium and its biochemical effect on selected tissues of the catfish (Clarias gariepinus). Fish Physiol Biochem 34, 61-69.

29. Richetti SK, Rosemberg DM, Ventura-Limar J, Monserrat JM, Bogo MR, Bonan CD (2011) Acetylcholinesterase activity and antioxidant capacity of zebrafish brain is altered by heavy metal exposure. Neurotoxicology 32, 116-122. 
30. Ventura EC, Gaelzer LR, Zanette J, Marques MRF, Bainy ACD (2002) Biochemical indicators of contaminant exposure in spotted pigfish Orthopristis ruber caught at three bays of Rio de Janeiro coast. Mar Environ Res 54, 775-779.

31. Eric DHD, Thomas BF, Patrick SF, Kai JE, David JO (2010) Natural factors to consider when using acetylcholinesterase activity as neurotoxicity biomarker in young-of-year striped bass (Morone saxatilis). Fish Physiol Biochem 37, 21-29.

32. Scott GR, Sloman KA (2004) The effects of environmental pollutants on complex fish behaviour: integrating behavioural and physiological indicators of toxicity. Aquat Toxicol 8, 369-392.

33. Sandahl JF, Baldwin DH, Jenkins JJ, Scholz NL (2005) Comparative thresholds for acetylcholinesterase inhibition and behavioral impairment in Coho salmon exposed to chlorpyrifos. Environ Toxicol Chem 24, 136-145.

34. De La Torre FR, Salibián A, Ferrari L (2000) Biomarkers assessment in juvenile Cyprinus carpio exposed to waterborne cadmium. Environ Pollut 109, 277-282.
35. Kägi JHR, Schäffer A (1988) Biochemistry of metallothionein. Biochemistry 27, 8509-8515.

36. Dang F, Wang XW (2009) Assessment of tissuespecific accumulation and effects of cadmium in a marine fish fed contaminated commercially produced diet. Aquat Toxicol 95, 248-255.

37. Baldwin DH, Spromberg JA, Collier TK, Scholz NL (2009) A fish of many scales: extrapolating sublethal pesticide exposures to the productivity of wild salmon populations. Eco Appl 19, 2004-2015.

38. Jalaludeen MD, Arunachalam M, Raja $M$, Nandagopal S, Showket AB, Sundar S, Palanimuthu D (2012) Histopathology of the gill, liver and kidney tissues of the freshwater fish Tilapia mossambica exposed to cadmium sulphate. Int $J$ Adv Res Biol Sci 2, 572-578.

39. Annabi A, Messaoudi I, Kerkeni A, Said K (2011) Cadmium accumulation and histological lesion in mosquitofish (Gambusia affinis) tissues following acute and chronic exposure. Int $J$ Environ 5, 745-756. 